\title{
THE SPECTACULAR GROWTH OF THE THIRD STREAM: THE EVANGELICALS AND PENTECOSTALS
}

The term "Evangelical" has a very broad meaning and scope. Many mainline ${ }^{1}$ churches in Indonesia, for example GMIM, GMIT, GMIH, GMIST, GMIBM, and GKI di Tanah Papua (formerly GKI di Irian Jaya), use this term (in Indonesian I stands for Injili) as more or less equal with "Protestant" (cf. the term Evangelisch in the German Church, i.e. Evangelische Kirche in Deutschland, and Evangelis used by another mainline church in Indonesia, GKE). ${ }^{2}$ In its very essence, every church actually may claim to be Evangelical. But what we mean by this term or category in this chapter is Christianity or churches identified by a conservative-evangelical character, although there is also a wide range of variety among them. ${ }^{3}$ Some of the 'mother missions' came from Europe, but most of them came from the USA; therefore to a certain extent they have a close affinity to the fundamentalism that emerged in the USA in the early twentieth century, besides inheriting the eighteenth century Pietistic and Revival spirituality which was also inherited by the mainline churches through their founding European missionary societies. ${ }^{4}$

\section{The gathering organisations}

Most of the Evangelical churches or denominations have joined in a special council called the Persekutuan Injili Indonesia (PII; Indonesia Evangelical Communion, founded in 1971), whereas the Pentecostal churches mostly are members of the Persekutuan Gereja-gereja Pantekosta di Indonesia (PGPI;

\footnotetext{
1 'Mainline' or 'mainstream' is actually a rather vague term. It is usually understood as a stream or cluster covering the churches faithful to the orthodox Reformation teachings, like Lutheran and Reformed or Calvinist. But in the further development the Methodist, and in some countries the Anglican, Baptist and the Mennonite are also included as mainline. We use this term here artificially just to make an arbitrary distinction between the 'traditional churches' (those that were founded by the European missions, especially coming from Lutheran and Reformed traditions) and the 'new churches' (those mainly founded by the American missions).

${ }^{2}$ See the abbreviations about the names.

${ }^{3}$ One of the definitions among the Evangelicals is as follows: Evangelicals are those who accept (1) the authority of the Scripture as the Word of God; (2) the essential nature of the atonement of Christ and an existential saving encounter with the Holy Spirit; and (3) the obligation of the church to evangelise non-Christians throughout the world. Arthur F. Glasser 1993, as quoted in: Albert R. Konaniah 1995.

${ }^{4}$ Cf. Ellingsen 1988.
} 
Communion of the Pentecostal Churches in Indonesia, 2001; formerly Dewan Pantekosta Indonesia, DPI, founded in 1979). There are also some Pentecostal churches in the PII, because they also claim or confess themselves as Evangelical (although some Evangelical theologians disagree with such a claim). Some of them have even joined the Persekutuan Gereja-gereja di Indonesia (PGI, where most of the members are mainline churches; see chapter seventeen), because they also claim to be bearers of the ecumenical spirit.

But not all Evangelical churches link up with the PII (up to 2001 there were 84 churches and mission agencies that had become full members). An example is the Gereja Reformed Injili Indonesia (GRII, the Evangelical Reformed Church in Indonesia, see below). On the other hand some of its members also join the ecumenical national council of churches (PGI), for example the Gereja Kristus Tuhan (GKT, the Church of Christ the Lord), officially founded in 1968 in Lawang, East Java (which also inherited and absorbed Methodist and Presbyterian traditions from the USA), Gereja Kristen Anugerah (GKA, the Grace Christian Church, Jakarta 1968), Gereja Kristen Kalam Kudus (GKKK, the Christian Church of the Holy Word, Jakarta 1973), Gereja Kristen Injili Indonesia (GKII, the Evangelical Christian Church in Indonesia, Bengkulu 1967), Gereja Kristen Injili di Indonesia (Gekisia, the Evangelical Christian Church in Indonesia, Bengkulu 1985, as a split off from GKII), Gereja Kristen Setia Indonesia (GKSI, the Faithful Christian Church in Indonesia, Jakarta 1988), Gereja Kristen Perjanjian Baru (GKPB, the New Testament Christian Church, Surabaya 1989), and Gereja Keesaan Injili Indonesia (Gekindo, the Church of Evangelical Unity in Indonesia, Jakarta 1993).

At an international or global level, many Evangelical churches and missions in Indonesia became members of the World Evangelical Fellowship (WEF, founded in 1951) and were represented in many international events, such as the World Congress on Evangelism in Berlin 1966, in Lausanne 1974, in Seoul 1982, and in Amsterdam 2000; whereas at a regional level the most recent congress was the South East Asia Congress on Evangelism (SEACOE), Singapore 2001. Through these congresses the Indonesian Evangelicals refreshed their spirit and insight on Evangelism and also widened their cooperation and networking with many ecumenical bodies outside the Evangelical group that were also invited to those events. On the other hand they also have had the opportunity to revisit their understanding of mission and evangelism, especially in relation to social-political issues and the pluralism of religions in this country.

\section{Resources and division of the chapter}

A comprehensive and analytical study regarding the history of the so-called Evangelical and Pentecostal Christianity in Indonesia is still to be awaited. 
Among more than 150 Evangelical and Pentecostal denominations or church and mission organisations in Indonesia, several began to write their respective histories; but most of them are merely descriptive or full with expressions of piety, and are usually focused on the founders, in the fashion of hagiography, with almost no theological and historical analysis. However, we have to use them as our sources, alongside some secondary sources, such as books, or chapters about them in more general books. Unfortunately we cannot utilise the primary sources because of the huge variety among them. Therefore this chapter can be perceived only as an embryo or initial effort and an incentive to them to provide a more comprehensive and complete picture regarding this category of Christianity.

In the following section we will find a chronological and institutional sketch regarding the presence and development of these Evangelical and Pentecostal missions, churches, and agencies. Corresponding to this historical description we will see briefly their respective basic-theological concepts and characteristics, which are the basis for their methods of mission or Evangelism. Then their methods and strategy will be described briefly. Finally we glance at the result and impact of their activities as well as their relationship with other churches and other religions.

\section{Chronological and Institutional Survey}

\section{The Evangelicals}

Since all missionary societies from Europe and America that came to Indonesia from the beginning of the nineteenth century professed the ideas and spirituality of Pietism and Revival, and since some of them joined the Evangelical Alliance founded in London in $1846^{5}$, we may consider their arrival in Indonesia as the beginning of the Evangelical missions. But since the meaning of 'Evangelical' in those societies is not precisely the same as what we mean by the term (see supra), and since most of the churches founded by these missionary societies became 'mainline' churches, we cannot identify these missionary societies as the carriers or representatives of the Evangelical missions and churches we discuss in this chapter.

Meanwhile the Baptists also claim or confess to be Evangelical ${ }^{6}$ and there are many prominent Baptist figures who are recognised as the leaders of Evangelical fellowships, like Billy Graham. ${ }^{7}$ Therefore we have to mention this denomination as the first Evangelical mission that arrived in Indonesia.

\footnotetext{
5 De Jonge 1998:21.

6 Aritonang 2003:138.

7 Cf. Aritonang 2003: chapter six.
} 
Moreover the Baptist Missionary Society (BMS) from England had already arrived and worked in Indonesia for the first time during the British era (1811-1816/1825), earlier than the continental missionary societies coming from Lutheran and Reformed backgrounds. A son of William Carey, the BMS missionary in India and the 'father' of modern mission, Jabez Carey, worked in Maluku in 1814-1818 (see chapter nine). From 1816 onwards Gottlob Bruckner, previously sent by the Dutch Missionary Society, worked for the BMS in Java (see chapter fourteen). Then Richard Burton and Nathaniel Ward worked in Sumatra in 1820-1825. Due to the termination of British rule in Indonesia, the Baptist mission had to leave, until it could come back again after Indonesian independence. Because these first Baptist missionaries did not establish any Baptist congregation ${ }^{8}$ (the first Baptist churches were only founded after 1950), the Baptists can also be categorized as a new church or denomination, like many other Evangelical denominations. Therefore we will add some basic information on this later Baptist mission.

In 1950 a number of missionaries of the Foreign Mission Board of the Southern Baptist Convention had to leave China. Some of them came to Indonesia and started a Baptist mission there (1951). The first baptism was administered in Bandung (West Java) on 23 November 1952. They also established a theological seminary and a publishing house in Semarang (Central Java, 1954), and a hospital in Kediri (East Java, 1955). Since then and particularly after the abortive coup of the Communist Party (1965), there were many Baptist missionaries from various mission agencies working in Indonesia. ${ }^{9}$ Like many other Evangelical missionaries from various mission societies, they also carried out mass baptisms for people who previously did not adhere to any official religion, and secured a large harvest, so that the post-1965 era can be conceived as a big harvest time for the Evangelical churches. ${ }^{10}$

Currently there are a number of Baptist denominations; among others 1. Gabungan Gereja-gereja Baptis Indonesia (GGBI, Federation of Baptist Churches in Indonesia, founded by the Indonesian Baptist Mission as a branch of the Foreign Mission Board of the Southern Baptist Convention, and which particularly works in Java and Sumatra); 2. Gereja Perhimpunan Injili Baptis Indonesia (GPBI, the Assembly Church of Evangelical Baptists in Indonesia, founded by the Conservative Baptists in the USA, which particularly works in West Kalimantan); 3. Persekutuan Gereja-gereja Baptis Irian Jaya (PGBIJ, the Communion of Baptist Churches in Irian Jaya, now Papua, which has its own seminary and hospital); 4. Kerapatan Gereja Baptis Indonesia (the Alliance of Baptist Churches in Indonesia), which particularly works in North Sulawesi

${ }^{8}$ Cf. Van den End et alii 2002:chapter 51.

9 For more detailed information see a.o. Smith n.d.

10 Willis 1977. 
but also in some other provinces, supported by the Canadian Baptists and the Southern Baptist Convention; 5. Sinode Gereja Kristen Baptist Jakarta (the Synod of the Baptist Christian Church in Jakarta); and 6. Gereja Baptis Independen (Independent Baptist Church) centred in Sunter, Jakarta. At least five of these churches assemble in the Persekutuan Baptis Indonesia (PBI; Communion of Baptists in Indonesia) and at least two of them have also joined the PII, although there is also a Baptist church which does not want to join any council or communion, the Gereja Baptis Independen. Total membership of these Baptist churches is more than 100,000, not including the children who are not yet baptised.

Turning to the Salvation Army (SA, Indonesian name: Bala Keselamatan) this denomination also claims to be Evangelical ${ }^{11}$ and had already commenced its mission in Indonesia in 1894 with the arrival of two officers from Holland, Captain J.G. Brouwer and Ensign A. van Emmerik. ${ }^{12}$ Because the SA has specific characteristics that distinguish it from most Evangelical missions and churches (organisational system, doctrine and practice, and its focus on social service parallel with Evangelism), we will only glance at it here. In Indonesia, as in its country of origin, England, and all over the world, the SA combines Evangelism and social service. The officers began their humanitarian service in Purworejo (Central Java) and the surrounding districts, and then widened their work to many provinces, with western Central Sulawesi (especially the Kulawi district) as the main focus. Here they developed education and medical outreach programs together with evangelism and social development. "Gifts, medical service, and education were key strategies for gaining converts in western Central Sulawesi. Yet Salvation Army leaders held good works as a major goal, not simply a felicitous by-product of the salvation of souls." ${ }^{13}$ One of the officers, Leonard Woodward, was very highly respected and honoured by the native people and they gave him a local honorary name Tua Janggo or Tua Jangku, meaning "Grandfather Beard." 14

To achieve its goal of service the SA was also active in the transmigration program to relocate poor people from Java to some agricultural areas in the outer islands. They also helped people who had suffered disaster and calamity, illness and poverty, by establishing orphanages, hospitals, schools, homes for the aged, etc., combined with Evangelism and pastoral care. To prepare and train its soldiers and officers, since the 1960s, the SA founded a big training centre in Jakarta. Since 1988 the SA in Indonesia has been transformed into

11 Aritonang 2003:260.

12 Brouwer 1994:1.

13 Aragon 2000:10, 114-115.

14 Aragon 2000:121. 
a church institution, rather than a social institution. ${ }^{15}$ While at social development level the SA became a member of the WCC, in Indonesia it became one of the "cooperating bodies" of the PGI. Currently it has around 3,500 officers and around 60,000 members.

Certain church historians point to the Christian and Missionary Alliance (CAMA, occasionally abbreviated CMA), initiated by A.B. Simpson in USA in the1880s, as a pioneer of Evangelical mission and churches in Indonesia, especially through the work of its famous missionary, R.A. Jaffray, from 1928. ${ }^{16}$ To a certain extent this is an accurate observation, as we see the CAMA's concept and method, as well as the role of the church cluster it founded-gathered under the so-called "Alliance" or Gospel Tabernacle cluster (Indonesian: rumpun Kemah Injil) - in the PII. The teaching of the CAMA can be summarized in four principles, usually called the "four-fold Gospel," i.e. Christ saves, sanctifies, heals, and will return as the Lord. The hope and conviction of the second coming of Christ and the Millennium Kingdom motivated its missionaries to proclaim the gospel to the people who had never heard and received it before. This evangelistic effort was conceived as hastening the return of Jesus Christ.

In 1928 Jaffray left China after he heard that there were thousands of Chinese migrants in Southeast Asia. After an orientation visit to some harbour cities in various areas in Indonesia, he established his evangelism ministry in Makassar in 1930, and then widened the scope of his mission to Bali, Lombok, Sumbawa, East and West Kalimantan, South Sumatra, and Irian Jaya (Papua), working in areas where so far there were no other mission societies at work. He recruited some Chinese missionaries brought from China and then added some missionary workers from the USA as well as Indonesia. Besides evangelising the Chinese, these missionaries also worked among indigenous people. They constructed 'Gospel Tabernacles' in native architectural style while also referring to the revival tradition in the USA with its 'tent meetings.' Besides Jaffray, one of the other prominent missionary figures was George E. Fisk who worked in East Kalimantan from 1929. He was highly honoured by the local people because of his appreciation and respect for their customs. ${ }^{17}$

Currently this cluster has developed into a number of churches (GKII, KIBAID, GKKA, Gepekris, GPMII, etc.) ${ }^{18}$ scattered in almost all provinces,

15 Ismail 1997.

161928 e.g. Van den End et al. 2002:280-282.

17 Conley 1976: passim.

18 GKII stands for Gereja Kemah Injil Indonesia (Gospel Tabernacle Church in Indonesia) and according to Scheunemann 1995:214 is the biggest evangelical church in Indonesia with almost 500,000 members; KIBAID for Kerapatan Injil Bangsa Indonesia (Gospel Alliance of Indonesian Nation), GKKA for Gereja Kebangunan Kalam Allah (Church of the Word of God's Revival), Gepekris for Gereja Persekutuan Kristen (Church of Christian Fellowship), and GPMII for Gereja Persekutuan Misi Injil Indonesia (Church of Mission Community in Indonesia). 
with more than 500,000 members. ${ }^{19}$ Besides establishing a number of elementary Bible schools in almost all mission fields, they also opened a number of theological seminaries (multiplied from one Bible School founded in 1930 in Makassar, South Sulawesi). One of them, the Institut Filsafat, Teologi dan Kepemimpinan Jaffray (IFTK, the Jaffray Institute of Philosophy, Theology and Leadership) in Jakarta, was for a long time (1986-2002) led by Rev. Yakob Tomatala D.Miss. before he was elected to be synod leader of GKII. ${ }^{20}$ This institute offers various degrees at undergraduate, graduate and post-graduate levels that become one of the attracting factors of this Kemah Injil group (regarding this, notice also the last paragraph of this section).

Since Jaffray was one of the founders of the Chinese Foreign Missionary Union (CFMU) in 1929 (after working for 30 years in China) and his former target of evangelism was the Chinese community in Indonesia, some of the 'Alliance' churches concentrated upon their activities amongst the Chinese, so that they (e.g. Gepekris, GKKA and GPMII) were also known as Chinese Evangelical Churches. ${ }^{21}$ But Jaffray and his successors did not only serve among the Chinese, they also worked among the indigenous people in East and West Kalimantan, and Papua. In these provinces there are autonomous churches of the Kemah Injil group with a quite large number of members, and which play an important role in developing the life of the community. ${ }^{22}$ One of the prominent figures of Kemah Injil in Papua at the moment is theologian and anthropologist Dr. Benny Giay.

Besides the above mentioned mission societies, there are many other Evangelical missions, mainly from the USA, that came to Indonesia from the beginning of the twentieth century. Their work, combined with the influence of the Revival movement initiated by John Sung in the 1930s in China and other Asian countries (including Indonesia), encouraged the founding of some evangelical churches, among the indigenous as well as the Chinese community. Not a few of these churches got their members from already existing mainline churches, so we may also perceive some of these churches as the effect of schisms among mainline churches. If we examine the membership list of the PII, we may find that most of them were founded during these last 40 years, in areas formerly served by the mainline churches. In many cases certain Evangelical missions in the USA and Europe supported their planting or development processes but there are also several Evangelical churches that emerged in areas where the mainline missions had not worked before, and where they succeeded in recruiting their members from non-Christian

\footnotetext{
19 Lewis 1995 and Van den End 2002:284.

${ }^{20}$ More detailed information regarding Tomatala, IFTK Jaffray and their theology, Scheunemann 1995: 214-238.

21 Lukas Chandra 1999; see also chapter nineteen.

22 Conley 1976 and Lewis 1995.
} 
communities. From wherever they attracted their members, together with the Pentecostals they show a spectacular growth in numbers.

There is one Evangelical mission that deserves special attention, the Overseas Missionary Fellowship (OMF). This mission is the successor of the China Inland Mission (CIM) founded by James Hudson Taylor. After the closing of China for Christian missions by the communist regime, CIM moved to some other countries in Asia and one of the countries it has served since the 1950s is Indonesia. Unlike many other Evangelical missions, OMF-under its Indonesian name, Yayasan Persekutuan Kristen Indonesia (YAPKI, literally Foundation of Indonesian Christian Communion)_supports many mainline churches in mission and evangelisation, training, literature, and theological education, and participates in the ecumenical movement. ${ }^{23}$ Therefore the mainline churches and their theological schools welcome the OMF, although they know that theologically OMF strongly promotes the Evangelical theology and spirituality.

As has been mentioned, not all Evangelical churches join the Evangelical or ecumenical alliances. One example is the Gereja Reformed Injili Indonesia (GRII) that was founded in Jakarta in 1989 as the follow-up of the Lembaga Reformed Injili Indonesia (Indonesian Evangelical Reformed Institution) founded in 1986, and followed by the Sekolah Tinggi Theologi Reformed Injili Indonesia (STT RII, the Indonesian Evangelical Reformed Theological Seminary) in 1991. This church together with the seminary, led by Rev. Dr. (hc) Stephen Tong, the 'Billy Graham of the East' ${ }^{24}$ and Rev. Dr Yakub B. Susabda, is very enthusiastic in claiming itself to be a restorer of the Reformed or Calvinist doctrine in Indonesia and at the same time a promoter of the evangelical spirit. ${ }^{25}$ This church and theological school has a very close and strong relationship with the Gereja Kristen Immanuel (Immanuel Christian Church) in Bandung, one of the Evangelical churches that is also promoted by the Tong family, as well as with the Seminari Alkitab Asia Tenggara (SAAT, South East Asia Bible Seminary) in Malang, East Java and with the Sekolah Tinggi Teologi Bandung (Bandung Theological Seminary) led by Rev. Dr. Joseph Tong, one of Stephen's brothers. We may even say that the STT-RII and the STT Bandung are two among a number of SAAT's 'children'.

This SAAT (formerly a Bible school, founded in 1952) was initiated by Dr. Andrew Gih, a missionary from China (sponsored by the Bethel Mission, an interdenominational mission from the USA), quite well known as a strong

\footnotetext{
${ }^{23}$ See John Suwahyo in Penuntun, July 1996:363-365.

${ }^{24}$ So called by Philip Teng in a foreword to Stephen Tong's 35 years ministry anniversary, Serving My Times 1992:4, as quoted in Scheunemann 1995:196.

${ }_{25}$ For more detailed information regarding Stephen Tong, GRII, STT-RII and their theology, see Scheunemann 1995:194-214.
} 
promoter of the Evangelical movement. It is not restricted or tied to certain churches or denominations. ${ }^{26}$ Since there are many members of the mainline churches-especially the churches with a strong Chinese background-who are influenced and attracted by Evangelical Christianity, the role of this seminary with its 'children' in promoting the evangelical spirit among the 'traditional' and Evangelical churches is remarkable. Not a few of the congregations of those churches send their members to study here or called their pastor-candidates from this seminary.

The Yayasan Persekutuan Pekabaran Injil Indonesia (YPPII, the Foundation of the Indonesia Missionary Fellowship) also deserves special attention. This foundation was established in 1960 at a small town, Batu near Malang (East Java, and was officially ratified as a mission foundation in March 1961, after some years of preparation. It followed the WEC Bible School, which was founded in 1959 (from 1961 using a new name, Institut Injil Indonesia, I-3, Indonesian Gospel Institute). This foundation was initiated by several persons and it was claimed by Octavianus as the first truly Indonesian missionary or evangelisation body. ${ }^{27}$ The central figure is Rev. Dr. (hc) Petrus Octavianus who began his evangelising activities among the students in Malang in $1954 .{ }^{28}$ He was supported by several Evangelical missionaries, especially Rev. Heini Germann Edey and Detmar and Volkhard Scheunemann from the Worldwide Evangelising Crusade (or the World Evangelism Crusade, WEC) in England and Germany. Later these twin institutions-YPPII and I-3-were also supported by mission societies from some other countries like the USA and Japan. The lecturers at the WEC Bible School/I-3 were appointed mainly by WEC, but the influence of Fuller Theological Seminary at Pasadena USA and some other Evangelical seminaries in the USA was increasingly felt.

According to M. Djami Radja Uly, one of the first students of $\mathrm{I}-3,{ }^{29}$ there are four spiritual pillars as specific strengths of WEC, YPPII and I-3: faith, holiness, sacrifice and fellowship. Linked to this, Klaus Wetzel also emphasized the influence and heritage of Pietism, especially Philipp Jacob Spener, in the theological education system developed in I-3. ${ }^{30}$ Regarding these spiritual characteristics, Sikitari wrote,

\footnotetext{
26 SAAT-Katalog 1995-1996:3-6; cf. Koch 1970:74-76.

27 Octavianus n.d.:3-5; Scheunemann 1995:187-194.

28 Although Octavianus had been preaching since 1950 he admitted that it was on November 20, 1957 that he repented and accepted Jesus Christ as his personal Savior, i.e. during an Evangelistic meeting led by Roland Brown from Moody Bible Institute (Sikitari 1990:6). This cataclysmic repentance is quite typical among the Evangelicals. More detailed information regarding Octavianus and his theology see in: Scheunemann 1995:288-302.

${ }^{29}$ Hadiwinoto et alii (eds.) 1995:230.

${ }^{30}$ Hadiwinoto et alii (eds.) 1995:213.
} 
The Theological Education Department of the IMF (YPPII) has four theological schools.... These theological schools include a strong emphasis on the spiritual life of the students for the Board [of the IMF] recognizes that the spiritual ministry in the church can only be carried out by men and women of God who have been brought to new life in Jesus Christ and are living out the Word of God. The primary requirement for acceptance was that the student evidences the new birth, God's calling and high motivation to sacrifice life if need be for the ministry. ${ }^{31}$

Accordingly, regarding the contribution of YPPII and I-3 to the church and Christian life in Indonesia as well as in Asia, Wetzel ${ }^{32}$ mentioned three objectives: 1 . to revive the traditional churches in Indonesia which were marked by spiritual decadence; 2 . to foster the development of Protestantism in Indonesia during the rapid phase of growth, especially since 1965; 3. to widen the ministry reach of the Indonesian servants of God through global mission service, like sending Indonesian missionaries to some Southeast and East Asian countries.

Up to the early 1980s YPPII and I-3 were warmly welcomed and supported by many churches, even the mainline or traditional churches, because the constitution of these institutions declared that they will not found any new church, but rather empower already existing churches by injecting them with the spirit of revival and Evangelism. ${ }^{33}$ But later, since 1984, this foundation with its affiliated theological/Bible schools established some new Evangelical churches; among others are the Gereja Misi Injili Indonesia (GMII, Evangelical Mission Church in Indonesia, or Indonesia Missionary Church) and Gereja Protestan Injili Nusantara (GPIN, Protestant Evangelical Church in Nusantara). These developments made many churches withdraw their recommendation and caused polarization between the evangelical and ecumenical wings. Some of the reasons for establishing new churches were explained by Octavianus as follows:

At that time [1984] the condition [in southern Sumatra where YPPII worked to evangelise the people, especially in Serawai, Bengkulu] demanded that there should be a church established.... Before going to Serawai, we stopped in Lampung to meet the pastor of the Javanese Church. In Palembang we arranged a meeting with pastors of the Javanese Church, GPIB (Western Indonesian Protestant Church) and the Methodists. We asked them to join us in Serawai and southern Bengkulu, to accept the decision if a church must be born. But we know that at that time it was not easy.... After serving there around two and half months, there were 299 baptised; all of them came from a non-Christian background. Therefore the church is born. As the leader of YPPII I named this church Gereja

31 Sikitari 1990:9-10.

32 Hadiwinoto et alii (eds.) 1995:216-217.

33 See for example Octavianus in: Wagiyono Sumarto et alii (eds.) 1998:1-3. 
Kristen Injili di Sumatera Selatan (Gekisus, Evangelical Christian Church in southern Sumatra). I also ordained several pastors in southern Bengkulu and Serawai... God gave me vision because formerly I already had experience.... God gave me an original charisma, without that there will be no YPPII. ${ }^{34}$

Through this explanation we see one of the main concepts and methods of the Evangelicals, that is church planting, which we will discuss later. We also find a typical example regarding the rise of Evangelical churches, that is the role of a central and dominating figure that usually claims to have received a special vision and calling from God, and to be proclaiming the Kingdom of God while simultaneously establishing a personal and family kingdom. ${ }^{35}$ It is also noteworthy that the leading figures of I-3 and YPPII as well as their derivate institutions-many of them coming from Octavianus' family-also hold important positions in the PII. As Wetzel ${ }^{36}$ pointed out, most of the board members of the PII are I-3 alumni, so that these twin institutions play an important role in the rise and development of the Evangelical movement and activities in Indonesia.

Since around the year of 2000 there has been a new development in I-3 as well as in some other Evangelical theological education institutions; they have invited several lecturers from ecumenical theological schools to be guest professors. This is actually not new, because in the beginning YPPII and I-3 also built a good ecumenical relationship with many church organisations, including the DGI/PGI. On the one hand this should be accepted gladly and thankfully, because this may recover the cracked relationship enjoyed before, but on the other hand it should also be observed carefully.

Particularly in the circle of theological institutions, in the1980s the Evangelicals founded a special association, the Persekutuan Sekolah-sekolah Teologi Injili di Indonesia (Pasti, Fellowship of the Evangelical Theological Schools in Indonesia), as a 'competitor' with the Perhimpunan Sekolah-sekolah Teologi di Indonesia (Persetia, Association for Theological Schools in Indonesia) founded by theological institutions mostly supported by the mainline churches. But not all of Evangelical theological schools become members of Pasti. STT RII, for example, prefers to be a member of the Persetia. As in the case of double or triple membership or affiliation among some Evangelical churches, there are also certain Evangelical theological schools that have become members of Pasti, Persetia, and even Perhimpunan Sekolah-sekolah Teologi Pentakosta di Indonesia (Pesatpin, Association of Pentecostal Biblical and Theological Schools in Indonesia). One example is the Institut Keguruan

\footnotetext{
34 P. Octavianus, "Gereja Misi Injili Indonesia (GMII)." (transcript of his speech in the opening session of the Synodal Assembly of GMII in 1996?). Later Gekisus was changed to GPIN.

35 Cf. Aritonang in Sumarto (ed.) 1998:94-96.

36 Hadiwinoto et alii (eds.) 1995:214.
} 
dan Teologi Indonesia (ITKI, Institute of Teaching and Theology in Indonesia), established by Gereja Bethel Indonesia (GBI, Bethel Church of Indonesia) that is also member of PGI and PII.

Still regarding theological education, in 2004 there were around 200 so-called Protestant theological schools or seminaries in Indonesia. More than 100 of them were established during the last 30 years and most of these new schools were established by Evangelical and Pentecostal churches and missions. Dealing with these Evangelical (as well as Pentecostal) theological schools, Herlianto ${ }^{37}$ noted that their strength is the evangelical and missionary spirit, besides a personal devotion that is frequently lacking in ecumenical theological schools in general. But the weakness is the lack of effort to adopt national education systems; consequently the curriculum and the degrees they confer do not meet the national standard decided by the government through the Department of National Education. There are even some Evangelical and Pentecostal schools that offer higher degrees, like Master of Divinity, Master of Theology, and even Doctor (including Doctor honoris causa), in only a few days, weeks, or months of quasi-study, without a thesis or dissertation, or by faking it. These degrees usually were awarded to or bought by businessmen, church leaders, or officials in certain government departments. This phenomenon can create the impression that theological schools in Indonesia, as some pseudo-theological education abroad, fall victim to commercialisation, which actually insults the quality of education and jeopardizes the future of the nation.

Besides these church organisations and theological seminaries, we also find hundreds of foundations or para-churches organisations, which also claim to be Evangelical. Until 2001 there were more than one hundred that became full members of PII, besides associate members. They work in varied fields and with diverse methods to support Evangelism directly or indirectly, through spiritual formation, education/schools, literature and mass media, physical and mental health care, information and communication (including radio and TV broadcasting), social service, etc. Among them we need to mention briefly a number of influential organisations.

Regarding ministry and spiritual formation among students there are at least two prominent organisations, the Lembaga Penginjilan Mahasiswa Indonesia (LPMI, Indonesia Institute of Student Mission, affiliated to the Campus Crusade for Christ in the USA), ${ }^{38}$ and Persekutuan Kristen Antar Universitas (Perkantas, Inter-Varsity Christian Fellowship, a split of LPMI and now affiliated to InterVarsity International). In the 1970s Perkantas was emerging as an assertive Evangelical alternative to the ecumenical student movement GMKI, which,

\footnotetext{
37 “Theological Education, a new commercialisation?" in: Hadiwinoto et alii (eds.) 1995:2954.

${ }^{38}$ Hery Susanto in: Penuntun July 1996:401-403.
} 
although affiliated internationally to the WSCM, had, up to that time, held the loyalty of Evangelical students. ${ }^{39}$

In the field of information and communication an institution deserving attention is the Lembaga Informasi dan Komunikasi Kristen Indonesia, LINK (Indonesian Christian Institute of Information and Communication) led by Dr. Iman Santoso. This institute regularly issues a Kalender Doa Nasional (National Prayer Calender) and a bulletin, Visi, Misi and Prakarsa (Vision, Mission and Motivation), distributed monthly to many churches and Christian institutions, not only among the Evangelicals and Pentecostals but also among the so-called ecumenical or mainstream churches. By doing this, and by showing a serious consciousness of Indonesian context and plurality, Iman Santoso and his group are also recognised as having a close relationship with the ecumenicals, including PGI. Santoso even joined as a board member of the Akademi Leimena, a 'think tank' established by the PGI (see chapter seventeen). ${ }^{40}$

The Yayasan Wahana Visi Indonesia (WVI, Foundation, affiliated to World Vision International in the USA) also deserves to be mentioned because-as an Evangelical institution founded by Bob Pierce in the USA-it pays full attention to social service. This is expressed in its Mission Statement, "World Vision is an international partnership of Christians whose mission is to follow our Lord and Saviour Jesus Christ in working with the poor and oppressed to promote human transformation, seek justice, and bear witness to the good news of the Kingdom of God." ${ }^{41}$ This foundation, previously named Lembaga Pelayanan Kristen Indonesia (LEPKI, Society for Christian Service in Indonesia), after some years of preliminary activities commenced service in 1962 in Malang, led among others by Rev. H. Germann Edey, the founder of the WEC Bible School/I-3 mentioned above. Therefore in the 1960s there was a very close cooperation and relationship between WVI and I- $3^{42}$ although it became looser in the following period. Based on such cooperation we see that Evangelicals (although not many of them) also pay attention to social service and perceive this to be one of the methods of a broader mission and evangelism.

\section{The Pentecostals}

The arrival of Pentecostal denominations in Indonesia was pioneered by the Bethel Temple Church from Green Lake, Seattle, USA. This church, through its leader, W.H. Offiler, sent two missionaries, Cornelius Groesbeek and Richard (Dirk) van Klaveren in 1921. They arrived first in Bali, translated the gospel

\footnotetext{
39 Personal observation of Simon Rae, ecumenical university chaplain, Bandung, 1972-1975.

${ }^{40}$ More information on LINK and Iman Santoso incl. their concept and strategy of mission, Scheunemann 1995:303-319.

${ }^{41}$ WVI, Who We Are (leaflet, n.d.), p. 3.

42 Raja Uly in: Hadiwinoto et alii (eds.) 1995:230-231.
} 
of Luke into Balinese, and distributed it during the Sunday service they conducted. They also performed divine healing and succeeded in bringing a number of people to believe in Christ. But then they were evicted from Bali by the Dutch colonial government according to its policy to close Bali for missionary work (see chapter fifteen).

The evangelisation programme spread to Surabaya and Cepu, East Java, since the Groesbeek family moved to Surabaya in November 1921, while the Van Klaveren family moved to Jakarta. In Cepu Groesbeek met pastor J. Thiessen and F.G. van Gessel, both of whom also played important roles later in the growth of the Pentecostal movement in this country. This Pentecostal movement and congregations grew rapidly so that on 23 March 1923 they founded the Vereeniging der Pinkster Gemeente in Nederlandsch Oost-Indie (the Union of Pentecostal Congregations in the Dutch East Indies) with its office in Bandung, chaired by D.W.H. Wenink van Loon. This organisation was recognised by the Dutch colonial government on 4th June 1924 with the name of de Pinkster Gemente in Nederlandsch-Indië (the Pentecostal Congregation in Dutch Indies), and later (in 1937) changed to de Pinkster Kerk in Nederlands Indie (the Pentecostal Church in the Dutch Indies) following a renewed recognition by the government. This name was again changed in 1942 to become the Gereja Pantekosta di Indonesia (GPdI), the largest of the Pentecostal churches in Indonesia up to the present, with more than three million members.

Since 1922 Cepu and Surabaya became centres of this Pentecostal movement which produced missionaries who later became forerunners of Pentecostal churches in Indonesia. Meanwhile Temanggung (Central Java) also grew as another centre, served by William Bernard (sent by a Pentecostal group in England) who was followed by the sisters M.A. Alt and F.N.M. Abkoude, who had been there before and were attracted by the Pentecostal teaching. Since then the Pentecostal churches have spread to many towns in East Java, West Java (pioneered and led by J. Thiessen in Bandung), the Moluccas, North Sulawesi, South Sulawesi, Timor, Kalimantan, Papua, Yogyakarta, Sumatra and the surrounding islands.

Van den End $^{43}$ observes that the first groups in society attracted to Pentecostal teachings were from Eurasian background. For a long time they were neglected by the mainline and state church (i.e. the Indische Kerk). The Chinese followed and some other ethnic groups that had been Christianised before, such as the Minahasan, Moluccan, and Batak groups. For the Pentecostal missionaries or evangelists, evangelising those who had been Christians before was not regarded as an act of hijacking or stealing sheep from other flocks but rather adding some new elements to their traditional Christian teaching and experi-

${ }^{43}$ Van den End 2002:272. 
ence, like the doctrine of being born-again or born-anew, the baptism of the Holy Spirit (as expressed by glossolalia), divine healing, etc.

One of the prominent phenomena in the development of the Pentecostal churches in Indonesia (as in many other countries) is the intensity of schism among them, even before their church was recognized by the government in 1937 as a kerkgenootschap (church institution). The first schism was in 1931 when M.A. Alt, the first woman missionary among the Pentecostals in this country, left the Pinkster Gemeente and formed a new organisation, Pinkster Zending (Pentecostal Mission), later renamed the Gereja Utusan Pantekosta. This schism was mainly caused by a doctrinal dispute. M.A. Alt refused to accept W.H. Offiler's teaching about God and his name, and she refused to accept Offiler's baptismal formula, "You are baptised into the name of the Father, the Son, and the Holy Spirit, namely the Lord Jesus Christ." This doctrine and formula is commonly known as 'Jesus Only.' She also rejected the limitation applied to women in preaching or pulpit service.

Besides that schism of 1931, Sumual, Senduk and Van den End ${ }^{44}$ also mentions further schisms during the period of the 1930s-1970s, among others:

(1) In 1932 the Pinkster Beweging (later called Gereja Gerakan Pentakosta), led by Rev. J. Thiessen, split from the Pinkster Gemeente;

(2) In 1936 Rev. R.M. Devin and R. Busby left the Pinkster Gemeente and together with Abkoude established the Gemeente van God (Sidang Jemaat Allah) then affiliated to the Assemblies of God in the USA that commenced its evangelism in Jakarta from the 1930s; this church also maintained the Trinitarian baptism formula and rejected the formula of Jesus Only;

(3) In 1941 Rev. D. Sinaga left the Pinkster Kerk and established Gereja Pantekosta Sumatera Utara (GPSU; the Pentecostal Church in North Sumatra);

(4) In 1946 Rev. Tan Hok Tjoan in Semarang left the GPdI and established Sing Ling Kauw Hwee, later called the Gereja Isa Almasih (GIA; the Church of Jesus Christ);

(5) In 1948 Rev. Renatus Siburian and Lukas Siburian left the GPdI and established Gereja Pantekosta Sumatera Utara (GPSU; the Pentecostal Church in North Sumatra, using the same name as that used by Rev. D. Sinaga);

(6) In 1952 Rev. F. van Gessel and H.L. Senduk left the GPdI and established Gereja Bethel Injil Sepenuh (GBIS; the Full Gospel Bethel Church);

(7) In 1957 G. Sutopo and Ing Yuwono split from GBIS and established Gereja Bethel Tabernakel (the Bethel Tabernacle Church);

\footnotetext{
${ }^{44}$ Sumual n.d.:78-81; Senduk n.d.:13-14; Van den End 2002:272-273.
} 
(8) In 1959 Rev. Ishak Lew split from the GPdI and established the Gereja Pantekosta Pusat Surabaya (GPPS; the Pentecostal Church Centred in Surabaya);

(9) In 1960 GBIS split again when A. Parera established the Gereja Nazareth Pentakosta (GNP; the Nazareth Pentecostal Church);

(10) In 1966 Rev. Karel Sianturi and Sianipar split from the GPdI and established the Gereja Pantekosta Indonesia Sumatera Utara (Indonesian Pentecostal Church in North Sumatra);

(11) In 1967 the Gereja Pentakosta Elim (GPE) was established in Surabaya and Timor;

(12) In 1970 H.L. Senduk and associates split from the GBIS and established the Gereja Bethel Indonesia (GBI; the Bethel Church in Indonesia), supported by the Church of God from Cleveland Tennessee.

When we trace further this story of schism up to the present time, we will find many more cases, and these schisms brought around a hundred new Pentecostal churches into existence. The most recent development is the split of the Bethany Church and the Tiberias Church from GBI in 2003 and 2004. These new churches were formerly two among a number of big congregations in GBI that then multiplied spectacularly. Besides the above-mentioned schisms, there are some other causes of this multiplication. One of them is the arrival of new Pentecostal denominations from the USA, like the United Pentecostal Church since 1939 in Central Java. This church initiated a new church called Gereja Pentakosta Serikat Indonesia centred in Semarang. Observing the development of the Pentecostal churches in Indonesia since the arrival of the Bethel Temple, Tapilatu ${ }^{45}$ concluded that the most striking influence came from American Pentecostals although there were also a few European missionaries. ${ }^{46}$

Since the 1970s, while the trend of schism still continued, there has also been another phenomenon, the trend of gathering. The Pentecostal churches formed the above-mentioned DPI/PGPI although not all of them joined this fellowship. Some of the Pentecostal churches even joined the national council, the DGI/PGI. This phenomenon shows an increasing interest among them to participate in the ecumenical movement, as we also find in international and global forums like the WCC. Meanwhile, in terms of quantity, we see not only a spectacular growth of church institutions but also an increasing number of members. Among around 17 million members of the so-called Protestant churches, at least 6 million are Pentecostals, including those still registered in

45 Tapilatu 1982:21-24.

${ }^{46}$ Cf. Sumual n.d.:76-77. 
some traditional or mainline churches. This number will become bigger when we include the participants of the Charismatic fellowships and worshipers that have been present within the mainline churches since the early 1970s. No wonder then if the Pentecostals in Indonesia, like their fellows all over the world, claim that, while in 1970s they became 'the third power' (besides the Roman Catholic and the mainline Protestant churches), in the near future they will become the first power.

In line with the multiplication of church institutions, and like the Evangelical churches, the Pentecostals are also very active in opening Bible schools. Already in 1935 they had opened the Netherlands Indies Bible Institute (NIBI) in Surabaya, sponsored by William W. Paterson, a missionary sent by the Bethel Pentecostal Temple in Seattle who then cooperated with Van Gessel. Now we can find more than a hundred Bible schools and many of them have been upgraded to become theological seminaries with a higher education level and offering various academic degrees. But they are only registered in the Department of Religious Affairs; none of them is registered at the Department of National Education or accredited by the national official accreditation body. This brings some difficulties for theological education to secure full recognition from the government. Therefore Herlianto's critical note mentioned above also applies here.

Although there is a number of Pentecostal Bible or theological schools, not all Pentecostal churches require those who want to be pastors to have had a previous theological education. According to their church order, there are three levels of pastors: helping pastor (pendeta pembantu; Pdp.), junior pastor (pendeta muda, Pdm.), and senior pastor (Pendeta; Pdt.). Someone may become a helping pastor when she/he succeeds in recruiting a certain number of members or followers. After fulfilling some more non-academic requirements she/he may be promoted to be junior pastor, etc. No wonder then if in certain Pentecostal churches we may find quite a large number of pastors, many of them professionals like engineers, physicians, or businessmen. This phenomenon becomes more glaring when they also apply the franchise system, attaching the name of a well-known congregation to a new one in return for a fee paid to the famous congregation, just like McDonalds!

\section{Charismatic Movement}

The picture of the Evangelicals and Pentecostals will not be sufficient unless we pay special attention to the Charismatic or Neo-Pentecostal movement. As already noted, not long after the emergence of this spectacular movement in the USA in 1960 it had already arrived in Indonesia, from the late 1960s or early 1970s. The spirit and strategy of this movement, in accordance with its initial inter-denominational characteristics, are not limited to the Pentecostals 
but are active also among the Evangelicals, and even among the ecumenical or mainline Protestant and Catholic communities. Below will see that some of its characteristics are also found with Pentecostals; here we will only note some attracting elements, followed by an observation of the charismatic movement among the Catholics.

One of the most attractive elements in the Charismatic fellowship or service is the way in which they celebrate worship (usually called Praise and Worship). There is cheerful and vivid music and hymns, an informal and flexible order of worship, and simple, practical preaching or Bible exposition. The participants-mostly coming from the traditional mainline churches where they feel bored-can express their feelings and emotion spontaneously by clapping, crying, dancing and the like. They don't have to squeeze their brain-tired after a whole week working-in order to understand the sermon but get some 'fresh amusement'. They just want to release themselves from the burden of their daily work by enjoying something ecstatic. In short, the worship is performed as an entertainment package. Anticipating this trend in worship and seeking to recover the reduced numbers of worship participants and activists among their members, some of the traditional churches try to modify their order of worship or perform what they call "alternative worship," especially for the younger generation. ${ }^{47}$

Another attractive element is the special attention and approach shown to business people. This has a tight link with the theology of success or theology of prosperity to be discussed later. As is commonly known, one of the embryos of this movement is the Full Gospel Businessmen's Fellowship International (FGBMFI) initiated by Demos Shakarian, an American of Armenian origin. This fellowship came to Indonesia together with the arrival of the Charismatic movement and in a short time succeeded in attracting a number of Christian businessmen as well as high government (including retired military) officers, followed by the establishment of what they called a chapter. ${ }^{48}$ Every chapter meets regularly in an informal and relaxed atmosphere, such as a coffee morning, happy hour lunch or leisurely dinner. Usually the fellowship, after a short welcome address, starts with music, singing and prayer, followed by scripture reading and testimony. On each occasion some of the participants give testimony regarding their success in business as well as in their whole life, which is full of God's abundant blessing. The demonstration of special charisma like

\footnotetext{
47 This policy was among others taken up by HKBP in its synod assembly in 2002 although thereafter it brought internal conflict in certain congregations.

${ }^{48}$ In 2003 FGBMFI Indonesia had around 25 chapters scattered in several big cities (Jakarta with more than 10 chapters, Surabaya, Semarang, Bandung, Medan, Makassar, Batam, etc.). The Indonesian chair is ret. Lieut. Gen. H.B.L. Mantiri. See its leaflet, 2004 edition.
} 
glossolalia, divine healing and prophesying is not compulsory. Such an occasion is also used for making business deals or negotiations. For young executives or businessmen this fellowship opens an opportunity to advance themselves. No data is available on how many of the members succeed in promoting their business, since the administration of this fellowship is rather loose, but the fact that the number of the chapters and the membership continues to multiply shows that this kind of fellowship is still attractive.

There is a suspicion that the Charismatics do not have a social concern because they are more self-centred or self-oriented. This is not always true. One of the Charismatic fellowships centred in Jakarta named Abba Love, whose members are mostly young executives and businessmen, shows an increasing social concern. It has a regular plan and program to help the street-children and the poor people in the slums by providing scholarship grants, health services and the like. The members of this fellowship evidently do not have a strong intention or commitment to the so-called structural or transformative diakonia as shown in the documents of the WCC or the PGI, but their interest and openness to building cooperation with certain Christian social service institution such as WVII shows that even the Charismatic circle perceives social ministry to be part of their Christian calling. ${ }^{49}$

The so-called mainline or traditional churches generally have mixed feelings and standpoints towards this Charismatic movement. On the one hand they cannot deny the fact that many of their members are attracted by this movement, by attending its fellowship and gatherings and then trying to bring what they understand as 'new spirituality' into their respective churches. On the other hand these mainline churches are aware of certain 'dangers' contained in this movement or stream, such as an extreme understanding and practice of charisma and its theology of success. Some of the mainline churches set certain guidelines for their members to help them by making clear their standpoint. ${ }^{50}$ Other churches set a regulation that those involved in the Charismatic fellowship can not become elected as elders or deacons or members of the board of certain commissions in the congregation..$^{51}$ These guidelines or regulations, however, did not prevent members of those mainline churches from taking part or from imitating in their spiritual life what they experienced in the Charismatic fellowship.

\footnotetext{
49 See a.o. The World Vision International Indonesia Annual Report of 2004.

${ }^{50}$ This is done by Gereja Kristen Indonesia (GKI) in their document "Pegangan Ajaran" that is always attached in its book of Church Order.

${ }_{51}$ This is for example stated in one of the decisions of the Synod Council of Gereja Protestan Indonesia bagian Barat (GPIB) in 1981 and is still applied up to the present.
} 


\section{The short but turbulent history of the Catholic Charismatic movements}

As already observed, Pentecostalism and the Evangelical movement are Protestant initiatives. However, there is also a Catholic variant that is commonly called the Charismatic Renewal within the Catholic Church. Its origin can be dated to a weekend meeting in February 1967 at Duquesne University in Pittsburgh, Pennsylvania. Some 25 students, participants of the Cursillomovement (founded in Spain in the 1940s) came together for the three-day weekend retreat that is the basic practice of that movement. They studied the book of Acts and included elements of the Pentecostal movement into their truly Catholic programme. They were lay people, working in an intellectual climate at universities, after the Second Vatican Council. A major element was the Baptism of the Holy Spirit, deemed necessary for full Christian life. Therefore they started "Life in the Spirit Seminars" that would become the backbone also for the Charismatic renewal in Indonesia. They soon established a Centre for Service and Communication (1969), the result of the Catholic expertise in organised Christian formation. The Committee on Doctrine of the National Conference of Catholic Bishops of the USA wrote a report, submitted to the bishops on 14 November 1969, that spoke with caution about this so-called Pentecostal movement, preferring the word Charismatic and mentioning the rebuke of emotionalism. The committee emphasized the strong biblical basis of the movement "which manifested itself abundantly in the early church." It advised those responsible to remain in close contact and to realise that in the Catholic Church there is a tendency to substitute religious experience for religious doctrine. Cardinal Leo Suenens of Belgium (1904-1996) became, within the universal Catholic Church, the strong advocate of the Charismatics. He was not the joyful and enthusiastic promoter as many hoped, and therefore was also several times criticised. He had a powerful successor. In the Encyclical Letter Evangelii Nuntiandi (1975) Pope Paul VI had some negative comments on the Charismatics, "[Par 58: In some regions] communautés de base come together in a spirit of bitter criticism of the Church, which they are quick to stigmatise as 'institutional' and to which they set themselves up in opposition as Charismatic communities, free from structures and inspired only by the Gospel." Pope John Paul II (1978-2005) had some more positive comments on the movement but emphasized the need to respect the proper Catholic hierarchy. In the 1990s the Vatican considered the Charismatic renewal on the same level as Opus Dei, Focolare and the Neo-catechumenate as "ecclesial realities."

In May 1976 bishop Leo Soekoto of Jakarta invited Father O’Brien SJ from Bangkok and another fellow Jesuit, H. Schneider from Manila, to give instruction on the Charismatic movement in Jakarta. They gave some English language retreats to selected small groups. This resulted in the first official 
Catholic Prayer Group (Kelompok Doa or Persekutuan Doa) in Jakarta in January 1977. Later these groups were called Persekutuan Doa Kharismatik Katolik (PDKK). Some 150 faithful became members in this first Indonesian speaking retreat. By the late 1970s the Carmelite Yohanes Indrakusuma, of Chinese descent, had started a group of his own in East Java. He would later start a great Charismatic group in West Java. In Jakarta the Jesuit priest Lambert Sugiri (the Javanese version of his Dutch name, Van den Heuvel) became the moderator of the group that was concentrated in the (mostly Chinese) business centre of Mangga Besar. The group soon became bigger and spread also to other dioceses outside the capital.

In early 1980 Sugiri published a 77-page tract on the Charismatic movements as part of a larger book, the four other authors being mainstream Protestants who were also quite uncertain about the rise of new movements and even churches. In his preface, Bishop Leo Soekoto started a curious chain of questions, "Is it allowed for me to practise yoga? Transcendental meditation? To consult traditional healers? Are the voices we hear from God's Spirit or from an evil spirit? Is it right to join a Charismatic Group?"52 In 1981 a first national convention was held in Jakarta, followed by Malang (1983), Salatiga (1985) and Bandung (1988). In 1983 the bishops published Pastoral Guidelines for the Charismatic Renewal. In 1986 Lumen 2000 was established as a special Charismatic Prayer Group, concentrating on the modern media, with its youth group Siloam. G. Koelman later replaced Father Sugiri as moderator of the Charismatics. $^{53}$

These very quick developments since the late 1970s led to a quite dramatic conflict involving a major Charismatic group in Jakarta, the Sungai Yordan or River Jordan group, that seceded with some 800 members from the Catholic Church and joined the Pentecostal Bethel Church in 1988. The leader of this group was an engineer Ignatius Marsudi Hardono, of Chinese descent, born in Semarang in 1942. Married to a dentist, with three children, he lived in the middle class district of Tomang, Jakarta. He had been baptised a Catholic in 1976 and became in 1978 the elder (ketua wilayah) for the section of his parish. This was still the period of mass conversions after the 1965 coup and the start of Soeharto's New Order. Within the Charismatic movement he had the status of an evangelist.

After the disastrous development of 1988 there were repeated warnings from the Catholic hierarchy against the movement. On 7 December 1997 the Archbishop of Jakarta, Julius Darmaatmadja, formally declared a ban on the Karpena Mission (after Karitas for charity or love and Pena, a pen for writing

\footnotetext{
52 Sugiri 1982:8.

53 G. Koelman 1996-2003.
} 
in line with 2 Cor. 3:3, "You are a letter from Christ, written not with ink but with the Spirit of the living God"). The ban included the excommunication of its leader, Petrus J. Loyani. This latter apparently had a history of serial conversions. As a graduate of the Bethel Theological School he was a Pentecostal Christian, but then studied at the Catholic Driyarkara Philosophy College, applied for recognition as a Catholic Charismatic in 1996, still considering his visionary experience of 12 November 1992 as the basis of his mission.

On 27 August 2003 the diocese of Jakarta issued another warning, signed by the Vicar-general B. S. Mardiatmadja (not by Archbishop Darmaatmadja) in Hidup, 23 November 2003. The letter summarised several dangerous aspects of the Charismatic Renewal and Prayer Groups (Persekutuan Doa). There was again a warning to remain close to the Catholic hierarchy, not too easily invite preachers from other Christian churches or even from other religions, not to exaggerate the power of evil spirits, let alone ask for exorcisms to be executed by unauthorized people. It was also a warning against the practice of the 'Family Tree retreat' (retret pohon keluarga, developed in the 1960s by the Hungarian-American psychiatrist Ivan Boszormeny-Nagy as Contextual Therapy), where marriage life was seen more from a psychological than from a social and juridical angle. Finally, it was suggested that the Charismatics work in small groups, like base communities, and not seek large audiences by organising meetings in great conference halls and luxurious hotels.

In 2002 the Catholic Charismatic Movement estimated that there were some 100 Prayer Groups with about 5000 members. That is not a large number, compared to the more than 6 million Catholics of the country at the time. But this is a quite rough estimate. Including sympathisers and incidental participants might lead to a much larger number. Meetings of Prayer Groups can easily collect from 200 up to 500 people. The Mass and Adoration, organised by the group around Father Yohanes Indrakusuma, assembled some 9,000 faithful in the Jakarta Sports Stadium of Senayan on 24 October 2003. There are no figures about people who practise serial conversion and move from Catholicism to Protestant Churches, but as we saw in the case of the Sungai Yordan movement, it happens also in Indonesia, although not on the same scale as in some Latin American countries. Besides, there are again and again new American spiritual movements that attract elite people who are culturally orientated towards the United States. One of these is the Choice Movement for single (but apparently also some married) Catholic adults to look at their lives, popular since its introduction in 1982, and Marriage Encounter that was introduced in 1975 as another initiative of Bishop Leo Soekoto of Jakarta. Marriage Encounter was considered by several priests to be very unusual in Indonesian culture, because it is based on very open expression of sentiments, with neglect of the common East Asian culture of shame, where people do not like to say unpleasant things to their partners. To the surprise of the Belgian 
priest Piet Nooy SVD who organised the first weekend meetings, middle class urban Indonesian couples were very open and took real profit from this opportunity to enrich their married life.

The movements discussed in this section have changed the character of a number of urban Catholic parishes in Indonesia, especially in Java. They are concentrated upon individual or family experiences, do not relate to the whole of the parish, let alone the reform of society. They see not the celibate, clerical way of life, but married family life as the basis for a modern Catholic spirituality. Until now the clergy in general have managed to keep the groups within the regular structure of the Catholic hierarchical organisation. Some aspects have even become more common for Catholic life in Indonesian in general. The greeting 'God bless you' (Ind. Tuhan memberkati) was even used by the Jesuit priest Dr. Mardiatmadja in his open and severe warning against Charismatics as quoted above.

A major clerical figure in the Catholic Charismatic movement is the learned Carmelite priest, Dr. Yohanes Indrakusuma. Born on 8 June, 1938 in Sumberkepuh, Warujayeng, Nganjuk, East Java from Confucian-Buddhist parents, he became familiar with Christianity through his school and was baptised in a Catholic Church on 14 April 1954 in Malang. He became a Carmelite priest (O.Carm) through his ordination in 1967. In 1973 he received a doctorate in Paris (Institut Catholique de Paris) on the basis of his dissertation on L'Homme Parfait Selon L'École de Pangestu. Étude de la spiritualité Javanaise et de sa rencontre avec le Christianisme. In 1982 he established a women's order, the Daughters of Carmel, and in 1986 an order for men (Carmelitae Sancti Eliae). The two orders seek to integrate Carmelite tradition with Charismatic Renewal in an open contemplative way of life with predominance on the life of prayer and contemplation. The international Carmelite Order recognized both orders as affiliated branches on 19 December 2002, but not much about them is found in the reports of the official Catholic hierarchy. In 1988 Indrakusuma moved from East Java to West Java, where he created a grand centre in the Puncak mountain resort, in the village of Cikanyere, with the help of two rich benefactors. In 2002 it had 252 beds for guests and was nearly always fully booked. Pesona Karmel (a booklet of Carmelites) said about him, "His encounter with the Charismatic Renewal in 1974 became a turning point in his ministry. Although previously he was a popular retreat mentor and spiritual teacher, the experience of the Holy Spirit gave him a new tune and new power in his preaching ministry." ${ }^{34}$

The Charismatics lay much stress upon psychology, but also physical healing may be an important factor for modern Catholics. This occurs also outside

\footnotetext{
${ }^{54}$ Pesona Karmel (a booklet of Carmelites) 2000:28.
} 
the sphere of the more urban and modernising Charismatics, practiced by members of the Catholic community who possess special healing power. A quite sensational event in 1987 in Langgur, Kai Islands, has been described by Laksono. The priest Yosep Somar from Tanimbar was so well-known for healing and consultation with Catholics, Protestants and Muslims alike in Kai that several thousands people (9,000 registered for a visit) gathered for several days around the airport and parish house seeking healing. ${ }^{55}$ Because of the reserved attitude of the official Catholic Church, not much is found in statistics and overall reports.

\section{Basic ideas, characteristics and goals}

What we find among Evangelicals and the Pentecostals worldwide and especially in the USA, including the five fundamentals of faith, ${ }^{56}$ is also valid for the Evangelicals and Pentecostals in Indonesia. In recent years there has been a consciousness and an attempt, especially among certain Indonesian Evangelicals, to develop a so-called contextual theology, but generally speaking their basic concept is still the same. In this section we will add further detail while summarizing the movements.

\section{The Evangelicals}

We will take the statement formulated by the PII (Indonesia Evangelical Fellowship) as the representative of this stream or cluster, as follows:

Indonesian Evangelicals called, redeemed, and sanctified by the Son of God and for the glory of his name, realise that they have been called to (1) experience the fellowship of believers as the body of Jesus Christ; (2) serve and bear the burdens of one another with a humble heart; and (3) witness and proclaim the gospel. Its goals among others are: (1) to build Christian fellowship as the realisation of the body of Christ, which is holy and universal; (2) to defend the gospel; (3) to protect the pure hermeneutic and teaching of the Word of God; and (4) to perform social works, such as health care and taking care of orphans. ${ }^{57}$

Adding to this statement, Konaniah quotes the words of Chris Marantika, the president of PII, in his small book: Kaum Injili Indonesia Masa Kini (Indonesian Evangelicals of Today) as follows, "Our God wants us to live and work in unity and interdependence. The motivation, methodology, and purpose of Christian ministry should be based on the "3-P" principles: praying together,

${ }^{55}$ Laksono 2002:202-209.

${ }_{56}$ These are (1) the inspiration and infallibility of the Bible; (2) the deity of Christ and his virgin birth; (3) the substitutionary atonement by Christ's death; (4) his literal resurrection; and (5) his second coming (Ellingsen 1988:49).

${ }^{57}$ Quoted from Anggaran Dasar PII (Constitution of PII), 1974, by Konaniah 1995:48-49. 
paying together, and proclaiming together." ${ }^{58}$ After analysing the Evangelicals' understanding of their mission, Konaniah ${ }^{59}$ concludes,

The Evangelicals (in Indonesia) affirm that the church has a mission in the world. Mission is true only if it aims at leading people to repentance. The supreme task of the church is to obey the Great Commission of God (Matt. 28: 19-20)-to proclaim the gospel of Jesus Christ to the ends of the earth. Christians are to have a genuine concern for the social and economic welfare of the people. But this must not eclipse the fact that their primary task is to proclaim the gospel to the whole world. There is no other way to acquire eternal salvation except through Jesus.

According to Evangelicals, the purposes of mission are (1) to proclaim the gospel and lead unbelievers to Christ; (2) gather new believers into local churches or plant new churches; and (3) to serve those who are in need. But the church should not forget the ultimate purpose-to share God's love to them. ${ }^{60}$

\section{The Pentecostals}

As has also been mentioned, among the Pentecostal churches in Indonesia we may find several doctrinal differences or even conflicts, as in their country of origin the USA. But we may also point out some general similarities found in their statements of faith that at the same time become their special characteristics. ${ }^{61}$ Firstly, as to the doctrine of baptism, they believe that there are two kinds of baptism: baptism of water (by immersion and given to believers, not to infants) and baptism of the Holy Spirit as the last stage of salvation and as indicated by glossolalia (speaking in tongues). Secondly, divine healing; they believe that this miracle still happens now in several ways. Some PentecostalCharismatic pastors perform this healing through revival meetings while others minister through personal contact and prayer (including through telephone and television). Certain pastors, like Yesaya Pariadji from the Tiberias Church, use what he calls "the anointing oil" (minyak urapan). ${ }^{62}$ Thirdly, the flexible, simple, and spontaneous liturgy or order of service that is usually completed with an altar call or altar service. They believe that the Holy Spirit will lead the leader as well the participants in what they want to do during worship, including the exposition and the interpretation of the Bible. Fourthly, belief in the second coming of Christ at the end of time. Some Pentecostals believed

\footnotetext{
58 Konaniah 1995:56.

59 Albert R. Konaniah was the President of SAAT in 1988-2000.

60 Konaniah 1995:73 and 115.

61 Aritonang 2003:188-192; Sianipar 2002:58-60, 156-157, 171; Senduk n.d.: 55-56.

62 At least since 2003 up to the moment of writing (2005) Petrus Octavianus, one of the prominent leaders of the Evangelicals, was also regularly invited by Pariadji to lead the "anointing oil" Sunday service in his Tiberias Church. No wonder that the common Christians have difficulty in seeing the difference between the Evangelicals and the Pentecostal-Charismatics.
} 
that Christ would come back in the year of 2000; therefore before that year there were many seminars and revival meetings that took that issue as their central theme. Although the parousia did not occur in 2000 they insist on holding on to the belief in the imminent return of Christ. ${ }^{63}$

Another prominent development among the Pentecostal and Charismatic groups since the 1980s is the so-called theology of success or theology of prosperity. This theology was first introduced by some American authors like Norman Vincent Peale, Kenneth Hagin and Robert Schuller, and then propagated in Asia especially by Paul (who later becomes David) Yonggi Cho from Korea. One of his prominent students and followers in Indonesia is Yakub Nahuway, the leader of the Mawar Saron congregation of GBI and since October 2004 elected to be the synod chairperson of this church. Then in some Pentecostal and Charismatic churches and fellowships since the 1990s we may also find the phenomenon of the Toronto Blessing, that is the evidence of the fulfilment of the Holy Spirit in some spectacular signs of ecstasy like holy laughter, holy groaning, holy roaring, holy crying and wiping, etc. This phenomenon took place first in the Vineyard Christian Fellowship in Toronto and then spread all over the world. Certain Evangelical theologians, like Herlianto ${ }^{64}$ are very critical of these elements of teaching and praxis but the Pentecostal-Charismatic theologians defend these ${ }^{65}$ Some Evangelical churches also adopt the theology of success, parallel with the claim of some Pentecostals that they are also Evangelicals, which makes it difficult to distinguish these two streams or confessional groups.

\section{Methods and Strategy of Mission and Evangelisation}

We find that Evangelicals and Pentecostals apply approximately the same methods and strategies, although we may find some difference in detail. Corresponding to this, according to Konaniah ${ }^{66}$ Indonesian Evangelical churches realise that the mission of the church is a holistic ministry. This means that the ministry of the church includes the proclamation of the gospel of Jesus Christ and social responsibility. If the church limits itself to social service, it ignores the spiritual welfare of man and distorts the biblical meaning of mission.

63 In 2003 Mangapin Sibuea, pastor of a Pentecostal church, prophesied that the parousia of Christ would happen on 10 November 2003. He gathered his followers who came from many places (Timor, Papua, North Sumatra, etc.) in a building close to the city of Bandung. The parousia did not happen and Sibuea was jailed. Some months later he was sentenced by the court to stay in prison for several years based on the accusation that he caused disorder in society.

64 Herlianto 1992 and 1995.

65 E.g. Bambang H. Widjaja 1996.

66 Konaniah 1995:75. 
Discussing the methodology of mission or Evangelism, Konaniah, referring to some prominent Evangelical leaders like Chris Marantika ${ }^{67}$ and Yakob Tomatala, said that the Indonesian Evangelical churches realise that personal Evangelism is an effective method to evangelise non-Christians. ${ }^{68}$ Another related method that is also effective and relevant to its context is household Evangelism. The structure of Indonesian society emphasizes the family and local community. Therefore, in evangelism and planting churches, Christians have to pay attention to these factors. The third method is mobilizing the laity. Among Indonesian Evangelicals there is a strong sense of urgency, "Now is God's time for Indonesia. Let us not miss the present opportunity because we hold on to an unbiblical concept of the role of the clergy that discourages lay contributions to the church." ${ }^{69}$

The fourth is formal education through public and Christian schools. Regarding this method and strategy, Konaniah, referring to some resources, gave an historical observation. After the abortive coup of the Indonesian Communist Party in September 1965, there was a new era for Christian mission. Since 1966 freedom of religion has been confined to the recognised religions (i.e. Islam, Protestantism, Catholicism, Hinduism, and Buddhism). Every Indonesian citizen has to adhere formally to one religion. Religion courses are obligatory in all schools from elementary through to university levels. Every student has to join a religion class. Thus the Christian evangelistic effort among the youth could be concentrated on establishing Christian schools. This approach has been very successful in the past and is still a wide open door. Regarding this fourth method, only a few Pentecostal churches paid attention to formal general education. Most of the schools they founded are related to evangelistic work, like Bible schools and seminaries. ${ }^{70}$

The fifth method is dialogue with people of other faiths, which shows a typical Evangelical understanding of it. Referring to Marantika and some other Evangelicals, Konaniah noted that Christians have often looked upon people of other faiths as enemies. ${ }^{71}$ Argumentation, condemnation, and confrontation have failed to win the people of other faiths. Dialogue is based on interpersonal relationship. The purpose of dialogue is to build bridges and create "points

${ }^{67}$ Chris Marantika is the founder of Sekolah Tinggi Theologia Injili Indonesia (STTII) and Universitas Kristen Imanuel (Ukrim) at Yogyakarta and was chairperson of PII in 1983-2002. One of the requirements for a student to finish her/his study at STTII is to establish a local congregation with at least 30 newly baptised members. Corresponding to this, Marantika's motto is "Indonesia 1:1:1—one church in every one of the villages in Indonesia in one generation," quoted in: Scheunemann 1995:239.

${ }_{68}$ Konaniah 1995:77.

${ }^{69}$ Konaniah 1995:83, referring to Herlianto (one of the prolific writers among Indonesian Evangelicals), "Peran-serta Kaum Awam dalam Pertumbuhan Gereja." [The Participation of the Laity in Church Growth]. 1989.

${ }^{70}$ Konaniah 1995:84-85.

${ }^{71}$ Konaniah 1995:86-87. 
of contact" in order to proclaim the gospel. Today the urgent need in both the Christian church and the world is mission-to evangelise those who are not yet Christians. Here we see that among the Evangelicals dialogue is also an opportunity to evangelise with a target or expectation that the partner in dialogue will be attracted to become a Christian or member of a church through baptism, although they forbid using force. Therefore Konaniah as an Evangelical theologian said,

Today we have to realise that the urgent need is to evangelise those who do not yet believe in Christ. If the church does not have a vision and burden to evangelise, it will die. Since in Indonesia Christianity is a minority religion, believers are to ask God for wisdom so as to act wisely. Christians are not to force anyone to believe or to use materials that provoke anger. In the Indonesian context, witnessing through dialogue (or personal evangelism) and love are necessities. ${ }^{72}$

The last method Konaniah mentioned is social responsibility. ${ }^{73}$ In this regard, while referring to some other prominent Evangelicals like M.S. Anwari and Peterus Pamudji, he said, "Christians must work against injustice. Yet the church cannot become a political action organisation." ${ }^{4}$ At this moment, Evangelicals have a unique opportunity to lead the church toward renewal in Evangelism and a Spirit-empowered search for peace and justice. Social justice is needed, but it cannot solve every evil. The root of social evils is sin. Only the gospel of Jesus Christ can adequately deal with sin. Therefore, churches have to be careful that they do not let social works blur their primary task-to preach the gospel of Jesus Christ. However more and more Evangelical and Pentecostal churches or foundations give their attention and dedication to social service, such as giving education and lodging for the street children.

There is another method not yet mentioned which is very popular and also frequently used by the Evangelical and Pentecostal-Charismatic groups, the Revival Meeting (Kebaktian Kebangunan Rohani, KKR). Their churches and institutions, including Bible or theological schools-either alone or jointly-frequently undertake this KKR, inviting mass crowds openly through radio or newspaper, and not infrequently calling it an "ecumenical gathering" or an "inter-denominational fellowship." Sometimes the events are given other names, like "Faith Refreshing Service," and every KKR is given a special theme such

72 Konaniah 1995:133.

73 Konaniah 1995:88-91.

${ }^{74}$ It is quite interesting to observe that since 2001 there are several prominent leaders of Indonesian Evangelicals and Pentecostals, like Ruyandi Hutasoit (a physician as well as evangelist who then became a pastor, and the leader of Doulos Foundation) and Jakub Nahuway, who jumped into the political arena by establishing a political party, Partai Damai Sejahtera (Party of Peace and Prosperity) with a dream of getting a big number of constituents and votes among the Christians in the impending General Election of 2004. This Christian party, however, was not really successful. It received $2.13 \%$ of the votes, nationally, and $5 \%$ in Jakarta. 
as "God's visit on our nation," "Our calling in this end of time," etc. YPPII together with its twin I-3, for example, has a tradition to perform what they call Annual Worship around one week at its campus in Batu. Thousands of people gather from all over the country, many of them-not to say most of them-coming from the mainline or traditional churches. ${ }^{75}$ Such occasions are usually filled with altar calls, calling the participants to strengthen their commitment and to dedicate their life to serve Christ, to confess their sin, or even to repent and accept Jesus as their Saviour and then to be Christian, and not infrequently accompanied by divine healing. Besides the traditional Christians, not few of the participants are new Christians recruited through such occasions. No wonder that many Muslims complain that these activities are only a trick of Christianisation (see later).

Sikitari added another method often used by the Evangelicals, Cross-Cultural Ministry. ${ }^{76}$ By this method he meant preaching the gospel to the people from various cultural backgrounds. They use the language, custom (adat) and art of the traditional tribes to communicate the gospel, in Indonesia as well in the other countries. It is noteworthy that since the 1960s there have been quite a lot of Indonesian evangelists, especially from the circle of YPPII, sent to many other Asian countries like Malaysia, Singapore, Thailand, Kampuchea, Hong Kong, Taiwan, Japan, Nepal, Afghanistan and Pakistan. Some of them even went to Europe, Latin America, and Africa. They evangelise the people by visiting them in their houses, arranging gatherings in open areas such as a market place, and using radio broadcasting. This was made possible among other things by cooperation with WEC.

These methods lead to one of the main purposes and goals of the Evangelicals, to gather new believers into local churches or to plant new churches. That is why there are so many new congregations and church organisations initiated by the Evangelical missions. Sometimes this has raised problems, either because they recruit their church members from the church congregations that already exist or they evangelise the people of other faiths. Of course, this is not a general phenomenon applied to all Evangelical and PentecostalCharismatic churches.

Summarising this description of methodology, Konaniah said that the Evangelicals stress that the command of God and the content of the gospel remain the same, though the methodology may differ according to the situation. ${ }^{77}$ They realise that it is inadequate to have a spiritual program without a correlative concern and compassion for the poor and oppressed. But the

\footnotetext{
${ }^{75}$ Sikitari 1990:13-21 also called these revival events Renewal Ministry and described three examples, i.e. in Timor (1964 onwards), in Bandung (1966), and in Serawak Malaysia (1973).

${ }^{76}$ Sikitari 1990:21-27.

77 Konaniah 1995:110.
} 
church cannot substitute another agenda for the Evangelistic work, and after comparing the Evangelicals with the Ecumenicals, Konaniah concluded, "The difference between Evangelicals and Ecumenicals is clearly illustrated by two important church organisations-the PII and PGI. These two organisations have different approaches in mission. The PII stresses the need for personal conversion to Jesus Christ. Thus its purpose is to build the Christian fellowship as the realisation of the body of Christ, which is holy and universal. The PGI emphasizes social justice. It pays attention to motivating local congregations to work together with other people who embrace other faiths in order to solve social problems and to struggle for justice and peace." 78

\section{Relationship with and Impact on other Churches and Religions}

As has been mentioned, the relationship between the Evangelicals-Pentecostals and the so-called Ecumenical or mainline churches varied from quite close and friendly up to highly tense. Especially regarding the Pentecostals, but this can also be applied to some Evangelicals, one of the main causes of the highly strained relationship is that they do not respect the comity, that is a mutual understanding not to invade the other mission or church fields. Consequently, many-not to say most-of the members of the Evangelical-Pentecostal churches came from the mainline churches. From Evangelical-Pentecostal perspective it is quite naturally so, because they believe that they bring a set of Christian doctrines and practice that will fulfil or add to the Christian doctrine and practice brought by the former missions. ${ }^{79}$

We cannot depict the whole story but we may take the development of the relationship between the YPPII and the DGI/PGI with its members as an example. As described by Sikitari, ${ }^{80}$ in the early years of the YPPII (1964-1979) this Evangelical foundation developed a very close relationship with the DGI and its church members. The YPPII supported a number of churches-among others is GMIT (the Evangelical Christian Church in Timor) - to grow in numbers as well in spiritual and human resources. Later on there was a growing tension in their relationship and cooperation. Sikitari mentioned three of the causes,

Firstly, the problem of loyalty [dealing with] spiritual gifts and spiritual authority that accompanied the ministry of IMF (YPPII) evangelists and pastors. This affected the lives of some pastors, presbyteries and members of some of the congregations. As a result, they felt more loyal to the evangelists and to IMF whose

\footnotetext{
78 Konaniah 1995:146.

79 Van den End 2002:275.

80 Sikitari 1990:34-45.
} 
ministry has been such a help for their lives. Secondly, the consequences of the spontaneous ministry of those who had experienced the renewal. Though they did not have theological training to share with others, they did have their experience with the Lord and their spiritual gifts.... Their ministry became a threat to the authority of the local church leaders who often felt that their ministry, moral life and spiritual life were being criticized by these new converts. Thirdly, theological problems arose. In general, reformed denominations inherited a theological understanding contrary to what was taught by those who experienced the renewal. Theological emphasis on new birth and repentance, for example, was a major disturbance for pastors and other church leaders from the reformed church's traditions. Also lively liturgy became a problem for those who were used to the Dutch style of worship. ${ }^{81}$

Besides these three causes, Sikitari also mentioned three issues adding to the tension between the Evangelical and the Ecumenical streams, especially between YPPII and DGI ${ }^{82}$ Firstly, the difference of work system; DGI handed over their ideas to be implemented by the member churches, whereas YPPII had to implement their own ideas. An example of this is the practice of calling people forward for repentance (altar calling). Secondly, the different understanding of Evangelism and mission. For the DGI and its members Evangelism is not for Christians, whereas for YPPII it is also for the Christians, to renew their lives. Thirdly, the idea of the church in relation to para-church movements. Those from mainstream congregations considered themselves as the church, and those from para-church organisations as less than the church. On the other hand, those from para-church organisations considered themselves to be spiritual and committed, whereas those from congregations were spiritually dead and therefore needed to be evangelised.

Sikitari does not forget to mention and acknowledge some activities of ministry used by the YPPII that insulted the member churches of the DGI. ${ }^{83}$ The YPPII involved members without asking permission from the congregation. In addition, the YPPII performed Holy Communion, ordained missionaries, had its own chapel, and was involved in church planting. According to the church structures, none of these aspects of ministry could be performed by para-church organisations such as the YPPII, because it was not a church. These issues led the DGI to decide in 1984 to break off the relationship with the YPPII.

This bitter experience encouraged the YPPII to rediscover its own direction and to seek for a new modus operandi. Based on the consideration and options given by the Direktur Jenderal Bimbingan Masyarakat Protestan (General Director of Protestant Guidance) of the Department of Religious Affairs on

81 Sikitari 1990:39-40.

82 Sikitari 1990:40-41.

83 Sikitari 1990:41. 
behalf of the Indonesian government, the YPPII decided to support the new converts who wanted to establish a new denomination under the ministry of the YPPII. The new denomination was founded in 1984 in West Kalimantan and formerly called the Indonesian Evangelisation Church (Gereja Pekabaran Injil Indonesia; GPII) but then changed to become the Indonesian Missionary Church (Gereja Misi Injili Indonesia, GMII).

Dealing with the relationship with the people of other faiths, especially Muslims, as already mentioned, the Evangelicals-Pentecostals are also aware of the importance of dialogue with people of other faiths. But many of these dialogues show an atmosphere of apologetic and polemic on doctrine rather than seeking for mutual understanding and respect. Aspects of the process and content of this so-called 'dialogue' were openly published and distributed by both sides in books, cassettes, disks and internet websites, and not infrequently aroused tensions and conflicts. Certain Evangelical-Pentecostal Bible schools or seminaries also encourage their students to win or recruit people of other faiths as one of the requirements to finish their study. For this goal some of the students, like certain evangelists or missionaries, use 'tricks' like giving food, clothes or money. The revival and divine healing meetings are also directed to people of the other faiths and this also raises a hurt and disturbed feeling, especially among Muslim people. ${ }^{84}$

The increase and development of the Evangelicals and Pentecostals in terms of quantity might be respected and saluted with astonishment and admiration. But the approaches and terminologies (such as newly born, repent, etc.) frequently used by some of them to their fellow Christians as well as to the people of the other faiths may also arouse an assessment that they want to show a kind of spiritual arrogance and superiority. No wonder that some observers concluded that while we can learn many good and inspiring things from them we also have to be critical, especially when we want to take into account seriously the inter-religious relationship. Singgih, ${ }^{85}$ for example, drew attention to the Evangelicals' concept of ecumenism as the fellowship of the newly born Christians. He also criticized their concept of salvation as maintaining the old adagium, extra ecclesiam nulla salus that tends to see the people of other faiths as communities that should be saved by asking them to present themselves for baptism.

${ }^{84}$ For example, a revival and healing meeting-called Festival 2003-in Bandung on 13-14 August, 2003 led by an American evangelist Peter Youngren in cooperation with a local committee composed of some Evangelical and Pentecostal denominations, made Muslim people very angry and disturbed. They called this meeting an effort to promote apostasy and they strongly protested and asked the police to disallow the venue. See Herlianto, "Kesaksian (1) dan (2)," accessed from www.yabina.org on 18-20 August 2003.

${ }^{85}$ Singgih 1994:19-27. 
The Evangelical-Pentecostal groups as well as the so-called Ecumenicals are aware that the tension between them will not bring any benefit and that the polarisation between these two wings is predominantly a western issue. Therefore since the 1990s quite a number of steps have been taken and ideas put forward to minimise the tension and polarisation. Theo Kobong in one of his writings (1991), offered an approach to find a solution by using an Asian idiom, "this as well as that," rather than using a western idiom "either or." Meanwhile there are a number of forums or gatherings initiated by both sides to discuss various national issues faced by all Christians and even by the whole nation (see chapter seventeen). More fruitful efforts and results are still to be expected in the future.

Meanwhile, it is quite interesting to note that after the tragedy of 11th September 2001 in New York there has been a remarkable reconciliation between radical and fundamentalist Evangelicals in USA in line with a strong antipathy against Muslims. The echo of this phenomenon was also felt in Indonesia, the country with the biggest Muslim population in the world, because most of the Evangelicals in Indonesia have affiliation and affinity with those in the USA. ${ }^{86}$ This may bring a potential and continuing conflict between Christians and Muslims during the following years. But the cooperation and mutual alertness of all Christians in Indonesia is expected to eliminate this potential conflict.

\section{Addendum about 'new churches'}

Besides those Evangelical and Pentecostal churches, there are also some other churches we can also categorize as 'new churches' in Indonesia, although globally speaking some of them are quite old churches. To mention some of them ${ }^{87}$ : Gereja Masehi Advent Hari Ketujuh ${ }^{88}$ (GMAHK, The Seventh-Day Adventist Church) that has already been for more than 100 years in this country, Gereja Ortodoks Indonesia (The Orthodox Church in Indonesia). Actually there are two types of Orthodox Churches in Indonesia. Gereja Ortodoks Indonesia, currently led by Archimandrite Daniel Bambang Byantoro, was established in the beginning of the twentieth century and is affiliated to the Eastern Orthodox Church in Greece, whereas another one, led by Bambang Noorsena, started

\footnotetext{
${ }^{86}$ See Gatra magazine, June 21, 2003, with its main theme "Gerakan Penginjil Radikal" (Radical Evangelist Movement), esp. pp. 24-36.

87 The general survey and description on these churches is also available in Aritonang 2003.

${ }^{88}$ The first Adventist missionary already arrived in Indonesia in 1900; starting in Padang, West Sumatra, among the Muslim communities, but then moved to Medan, North Sumatra, and since then covered almost all provinces in the country. This church grows steadily and runs a lot of schools (from Kindergarten to university), hospitals and a publishing house (especially publishes book, booklets and magazines on health).
} 
from the 1990s, is affiliated to the Syrian Orthodox Church, uses Arabic, and call itself a study church which means only founded to do some study and research rather than recruiting anybody to be its member. The Orthodox churches are members of the WCC.

Other churches are Gereja Pertama Kristus Ahli Ilmu Pengetahuan (The First Church of Christ Scientist), ${ }^{89}$ Gereja Yesus Kristus dari Orang-orang Suci Zaman Akhir (The Church of Jesus Christ of the Latter-Day Saints), ${ }^{90}$ and Saksi-saksi Yehuwa di Indonesia (Jehovah's Witnesses in Indonesia). ${ }^{91}$ All of these churches are also registered in the Department of Religious Affairs. There are also still a few churches not yet officially registered, like the quasichurch of New Age Movement. But the space limitation makes impossible to give more detailed analysis.

Jan S. Aritonang (main text) and Karel Steenbrink (Catholic Charismatics)

\section{Bibliography}

Anonymus

1994 Institut Theologia Aletheia 1969-1994 (25th Dies Natalis Book). Lawang: ITA.

1995 Seminari Alkitab Asia Tenggara-Katalog 1995-1996. Malang: SAAT.

1997 Agenda dan Strategi Doa Pribadi 1997. Jakarta: Yayasan Doulos.

2002 "Ladang Sudah Menguning dan Matang untuk Dituai-Limapuluh Tahun GBIS Mengabdi Ibu Pertiwi Mengemban Amanat Agung Yesus Kristus, 21 Januari 1952-21 Januari 2002." Surabaya: Sekretariat Badan Penghubung GBIS.

2003a Almanak Kristen Indonesia (AKI) 2003. Jakarta: PGI.

2003b Sekolah Tinggi Theologi Reformed Injili Indonesia-Katalog 2003-2008. Jakarta: STT RII.

Aritonang, Jan S.

1998 "Kaum Injili di mata Gereja-gereja Arus Utama di Indonesia," in: Wagiyono Sumarto et alii (eds.), Dipanggil untuk Melayani (Buku Penghargaan untuk 70 Tahun Pdt. DR. Brouwer, Melattie M.

P. Octavianus). pp. 85-96. Batu-Malang: Departemen Literatur YPPII.

1994 Sejarah Gereja Bala Keselamatan di Indonesia, vol. I (1894-1950). Bandung Kantor Pusat Teritorial Gereja Bala Keselamatan di Indonesia.

89 This Christian Science denomination was already established in Indonesia since the 1950s.

90 This Mormon denomination started in Indonesia from 1970; in 1981-1985 it was inactive due to some restrictions made by the Indonesian government, but then from 1985 it recovered up to the present. It shows a remarkable growth in Indonesia as also happened globally, because among other things it distributes various kinds of aid to the community, including to the victims of the tsunami and earthquake disasters in 2004-2005, besides showing a special respect and honor to Islam and to the prophet Mohammad (see an article on this theme in one issue of their monthly Liahona in 2002).

${ }_{91}$ This religious group also claims to be Christian although the mainline churches generally call it a cult. The missionaries started to work in Indonesia since 1950s. In 1976 the government banned it because its activity was considered as disturbing religious harmony. But since 2001 the government of the 'Reformation Era', led by Abdurrahman Wahid who is well-known as a proponent of democracy, cancelled the ban and gave this sect a new opportunity. During the ban period many of the followers were still active under a different name. 
Daun, Paulus

1986 Apakah Evangelicalisme itu? Manado: Yayasan Daun Family/Yogyakarta: Andi Press. Ellingsen, Mark

1988 The Evangelical Movement; Growth, Impact, Controversy, Dialog. Minneapolis: Augsburg Publishing House.

Glasser, Arthur F.

1993 The Evangelical Mission. Grand Rapids: Wm. B. Eerdmans.

Hadiwinoto, K. et al. (eds.)

1995 Pendidikan Teologi Injili-Suatu Alternatif? Malang: STT "I-3".

Herlianto

1992 Teologi Sukses. Jakarta: BPK Gunung Mulia.

1995 Toronto Blessing_Lawatan Roh Allah Masakini? Bandung:Yabina.

1995a "Pendidikan Teologi, Sebuah Komersialisasi Baru?", in: K. Hadiwinoto, et alii (eds.),

Ismael, Dina Pendidikan Teologi Injili-Suatu Alternatif? pp. 29-54. Malang: STT "I-3".

1997 Sejarah Gereja Bala Keselamatan di Indonesia. vol. II (1951-1994). Bandung: Kantor Pusat Teritorial Gereja Bala Keselamatan di Indonesia.

Jonge, Chr. de

1998 Apa itu Calvinisme? Jakarta: BPK Gunung Mulia.

Karunia Djaja, Th.

1993 Sejarah Gereja Pantekosta di Indonesia. Semarang: GPdI.

Kobong, Th.

1991 "Baik Ini, Maupun itu" - suatu upaya mengatasi polarisasi antara kaum "Injili" dan kaum "Ekumenikal." (Dies Natalis Oration at STT Jakarta's 57th Anniversary).

Koch, Kurt

1970 The Revival in Indonesia. Berghausen: Evangelisation Publishers.

Konaniah, Albert R.

1995 "The Comparative Study on the Missionary Methodologies of the Evangelical and Ecumenical Churches in Indonesia." Jackson, Mississippi: Reformed Theological Seminary. (D.Min. dissertation).

Lewis, Rodger

1995 Karya Kristus di Indonesia. Bandung: Kalam Hidup.

Lukas Chandra

1999 Sejarah 70 Tahun CFMU 1929-1999. Jakarta: Gereja Persekutuan Kristen.

Marantika, Chris

n.d. Kaum Injili Indonesia Masa Kini. Surabaya: Yakin.

Octavianus, $\mathrm{P}$.

n.d. "Gereja Misi Injili Indonesia." Malang.

1998 "Gerakan Injili di Indonesia dalam Pengabdian dan Pembangunan Bangsa," in: Wagiyono Sumarto et alii (eds.), Dipanggil untuk Melayani (Buku Penghargaan untuk 70 Tahun Pdt. DR. P. Octavianus). pp. 1-27. Batu-Malang: Departemen Literatur YPPII.

Roemokoij, Danny

200180 Tahun GPdI (1921-2001) Menyongsong Tuaian Global. Jakarta: GPdI.

Scheunemann, Rainer

1995 "Mission und Evangelisation aus der Sicht Indonesischer Protestantischer Theologen." D.Theol. thesis Leuven.

1998 "Misi dan Penginjilan dari Sudut Pandang Theologia-theologia Indonesia", in Wagiyono Sumarto et alii (eds.), Dipanggil untuk Melayani (Buku Penghargaan untuk 70 Tahun Pdt. DR. P. Octavianus). Batu-Malang: Departemen Literatur YPPII, pp. 119-139.

Sekretariat Badan Penghubung Gereja Bethel Injil Sepenuh

2002 Ladang Sudah Menguning dan Matang untuk Dituai-50 Tahun GBIS. Surabaya: n.p. Senduk, H.L.

n.d. Sejarah GBI: Gereja Nasional yang Termuda. Jakarta: n.p.

Sianipar, Desi

2002 "A Historical-Comparative Study on the Mainline and the Pentecostal/ Evangelical Churches. Especially regarding the Development of Several Doctrinal Subjects and Worship Practices in HKBP and GBI." Jakarta: SEAGST. (M.Theol. thesis). 
Sikitari, Samuel A.

1990 "The Indonesia Missionary Fellowship in Light of the Two Structures of Mission." Pasadena: Fuller Theological Seminary. (M.A. in Missiology thesis).

Singgih, E.G.

1994 "Bagaimana dengan Kaum Injili (Evangelical)?," in: J.B. Banawiratma SJ et alii (eds.), Soedarto Tempat dan Arah Gerakan Oikumenis. pp. 17-29. Jakarta: BPK Gunung Mulia.

1996 "Visi dan Misi World Vision Indonesia," Penuntun. Theological Journal 2-8:353-362.

Sugiri L. et al.

1982 Gerakan Kharismatik: Apakah Itu? Jakarta: BPK Gunung Mulia.

Susanto, Hary

1996 "Visi dan misi Lembaga Pelayanan Mahasiswa Indonesia (LPMI) dalam Gerakan Oikoumene di Indonesia," PENUNTUN-Theological Journal 2-8:401-414.

Suwahyo, John

1996 "Visi dan Misi Yayasan Persekutuan Kristen Indonesia-Overseas Missionary Fellowship (YAPKI-OMF) dalam Gerakan Oikoumene di Indonesia," PENUNTUN-Theological Journal 2-8: 363-374.

Smith, E.C.

n.d. Perkembangan Gereja-gereja Baptis. Semarang: Seminari Theologia Baptis.

Sumual, Nicky J.

n.d. 60 Tahun Pantekosta Indonesia-Suatu Sejarah. n.p.

Tapilatu, M.

1982 Gereja-gereja Pentakosta di Indonesia (M.Th. thesis). Jakarta: STT.

Uly, M. Djami Radja

1995 "Sejarah Berdirinya STT I-3 d/h Institut Injil Indonesia", in: K. Hadiwinoto et alii (eds.), Pendidikan Teologi Injili-Suatu Alternatif? pp. 219-242. Malang: STT "I-3".

Wagiyono Sumarto et alii (eds.)

1998 Dipanggil untuk Melayani (Buku Penghargaan untuk 70 Tahun Pdt. DR. P. Octavianus). Batu-Malang: Departemen Literatur YPPII.

Wetzel, Klaus

1995 "STT I-3 dan Sejarah Gereja Indonesia", in, K.Hadiwinoto et al. (eds), Pendidikan Teologi Injili-Suatu Alternatif? pp. 209-218. Malang: STT "I-3”.

Widjaja, Bambang $\mathrm{H}$.

1996 Menguji Batu Penguji. Surabaya: Yayasan Masa Depan Cerah.

Willis, Avery T.

1977 Indonesian Revival-Why Two Million Came to Christ? South Pasadena: William Carey Library. 